\title{
Warm mix asphalt mixture using modified asbuton semi extraction modify and synthetic zeolite additive
}

\author{
Leo Sentosa ${ }^{1, *}$, Bambang S Subagio ${ }^{1}$, Harmein Rahman ${ }^{1}$, and R. Anwar Yamin ${ }^{2}$ \\ ${ }^{1}$ Department of Civil Engineering, Institut Teknologi Bandung, Bandung, Indonesia \\ ${ }^{2}$ Pusat Litbang Jalan dan Jembatan, Bandung, Indonesia
}

\begin{abstract}
Modifying asphalt aims to improve the performance of the asphalt pavement construction as indicated by increased resistance to permanent deformation and fatigue crack. Asbuton Semi Extraction is one of the materials that can be used for asphalt modification. The addition of Asbuton semi-extraction increases the value of Bitumen Stability Modulus, resistance to permanent deformation and can also increase the asphalt PG value, but require a higher temperature for mixing and compaction. The high temperatures for the manufacture of asphalt mixtures require considerable energy at a more expensive cost and will result in large emissions. The asphalt mixing technology currently being developed is Asphalt Warm Mix, that is asphalt mixture with mixing temperature below $1500^{\circ} \mathrm{C}$. One method is to use zeolite additives. The asphalt mixture with the addition of synthetic zeolite can be prepared by mixing and compaction temperatures lower than $30^{\circ} \mathrm{C}$ of the hot mixture. From the Marshall test, it is known that zeolite addition of $0.3 \%$ of the total weight of the mixture gives the characteristic values of the asphalt mixture which still meets the requirements of the specification used. Increased zeolite levels minimize the value of mixed resistance to the immersion indicated by the IRS Marshall value.
\end{abstract}

\section{Introduction}

Modified asphalt and asphalt mixtures aim to improve the performance of flexible pavement construction. Material for modification and asphalt modification results are acceptable if, material is available and accessible to obtain, resistant or not degraded at the temperature of bitumen mixing, thoroughly mixed with bitumen, improves resistance to flow at high surface temperatures without making mixtures too viscous at mixing and compacting temperatures or too stiff at low and cost-effective surface temperatures. One of the requirements of asphalt modification acceptable and applied is that it must have an impact on the service life of the pavement indicated by increased resistance to permanent deformation and fatigue in simulative experiments [1]. Besides polymer, Asbuton is one of the materials that can be used for asphalt modification [2].

${ }^{*}$ Corresponding author: leo_sentosa0@yahoo.co.id 
Buton Rock Asphalt is natural rock asphalt from Buton Island, Northwest Sulawesi, Indonesia and it is named locally as Asphalt Buton or Asbuton. The consistency of its bitumen varies from low to high penetration grades. The deposits are located in different places along the island. Total Asbuton deposits on the island are estimated at 677,247,000 tons [3]. Until late 1990s Asbuton was used extensively in its natural state as a surfacing layer for existing road pavements in the highway maintenance and betterment programmed in Indonesia. Use of these materials was then suspended by the Directorate General of Highways, due to "underestimated" performance of the mix, as mentioned above. On the other hand, extensive maintenance and betterment of the Indonesian road network involve the use of huge quantities of bitumen-bound materials. Given the relatively high cost of petroleum asphalt, much of which is imported from another country, and the existence within the country of large resources of rock asphalt, the outcome of the research of natural rock asphalt becomes significantly crucial for those involved in the highway maintenance programs [4].

One of Asbuton processing results is semi-extraction Asbuton which is produced by separating between bitumen and mineral Asbuton, then some of the mineral content is discarded, and produce Asbuton with a lower mineral content than the original [5]. Semiextraction Asbuton can be easily mixed with petroleum asphalt because it has experienced the breaking of the mineral bond with its bitumen through extraction [6]. The use of semiextraction Asbuton is now as a pre-blended Asbuton, which is a mixture of semi-extraction Asbuton with petroleum asphalt Pen 60 or 80 with a specific composition at $155^{\circ} \mathrm{C}$ to produce modified asphalt with the desired characteristics. Pre-blended Asbuton is a type of Asbuton utilization technology that is currently considered most promising for use as a binder on asphalt mixtures [7]. The method of pre-blended Asbuton in asphalt mixtures can improve resilient modulus [8], increase the resilience of asphalt mixtures to water $[8,9]$ and increase the strength of asphalt mixtures to high temperatures [8]. The use of Retona ${ }^{\circledR}$ one type of Asbuton pre-blended as an asphalt modification can improve the service life of pavement with the heavy load [2]. Modification of asphalt with Asbuton semi extraction in the form of pellets as much as $20 \%$ of asphalt weight gave the advantage of increasing the resistance of the asphalt mixture to fatigue. Asphalt modification with semi extraction Asbuton is more elastic and less viscous when compared with asphalt without Asbuton modification [10]. Asphalt modification Asbuton semi extraction requires higher mixing and compaction temperatures than on petroleum asphalt [11], suggests mixing temperatures using asphalt modification Asbuton semi-extraction is $170-176^{\circ} \mathrm{C}$ and compacting temperature $155-162^{\circ} \mathrm{C}[12]$, stated that the ideal mixing temperature was at $170^{\circ} \mathrm{C}$, and compaction temperature of $156^{\circ} \mathrm{C}$. The high temperature required for mixing and compaction of the asphalt mixture indeed requires considerable energy at a higher cost and will also produce significant emissions.

One of the asphalt mixture technologies that are being developed lately is Warm Mix Asphalt (WMA), which is an asphalt mixture with mixing temperatures below $150^{\circ} \mathrm{C}$ [13]. The process used in making warm mixed asphalt is a double coating, foam asphalt, and the use of some additives such as zeolite, or organic additives such as paraffin or other types of wax. However, all have the same primary purpose, namely to reduce the viscosity of asphalt to be able to be produced, transported and spread and compacted at lower temperatures without reducing mixed quality and workability. Asphalt this warm mixture due to fewer emissions and a reduction in costs due to less energy use [14], facilitating the process of mixing and compaction, even in unfavorable climatic conditions [13]. Also, the production of lower temperatures also means slowing aging binder or asphalt, and regarding workability, the reduced viscosity helps the aggregates to be coated more efficiently $[14,15]$. 
One of the most common WMA techniques is the addition of synthetic zeolite to the asphalt mix; it is by using the easiness of the additive storing and handling operation. Furthermore, conventional mix plants do not endure for the synthetic zeolite, available in granular form, can be easily added to the mix utilizing an external dosage device. Meager quantities of material (about $0.3 \%$ of the total aggregates weight) are used in the mixing process [16]. Zeolite is a group of alumina-silicate fractures that occur in nature with high cation exchange capacity, high adsorption, and hydration-dehydration. Water can be trapped in the zeolite structure of $18-21 \%$ of the weight of the zeolite. The trapped water can evaporate in the asphalt mixing process, and the water vapor will form the foam with asphalt so that the asphalt viscosity value can be achieved at lower temperatures than the temperature of the hot asphalt mixture [17]. A previous study [13] states that the best release of moisture content is zeolite particles releasing moisture in several stages rather than at once. The gradual release process takes place within a period of six or seven hours, during which time the optimum mixture workability and the temperature remains above $100^{\circ} \mathrm{C}$. While [14] states water in the zeolite structure will evaporate if the heating reaches $85^{\circ} \mathrm{C}$. Another researcher [16] indicates the use of synthetic zeolite can lower the temperature of making $30^{\circ} \mathrm{C}$ asphalt mixture lower than hot mix asphalt. Higher temperatures have an adverse effect on water sensitivity. The results obtained for the studied mixes confirm that a reduction of temperature by $30^{\circ} \mathrm{C}$ is possible when using zeolite without affecting asphalt mix performance.

This study investigates the feasibility of utilizing WMA with Asbuton semi-extraction modified asphalt mixtures and synthetic zeolite as an additive to lower the temperature of mixing and compaction. Test method Is empirical testing with Marshall test. Characteristic Marshall of WMA specimens containing synthetic zeolite was analyzed and compared with HMA specimens.

\section{Materials and methods}

The material used in this research is petroleum asphalt penetration grade 60/70 Pertamina production, Asbuton semi extraction Retona ${ }^{\circledR}$ briquette type production of PT. Olah Bumi Mandiri as bitumen modification which is packed in sacks weighing $40 \mathrm{~kg}$, Aspha-min ${ }^{\circledR}$ synthetic Zeolite additive, and processed aggregate PT. KADI International Karawang.

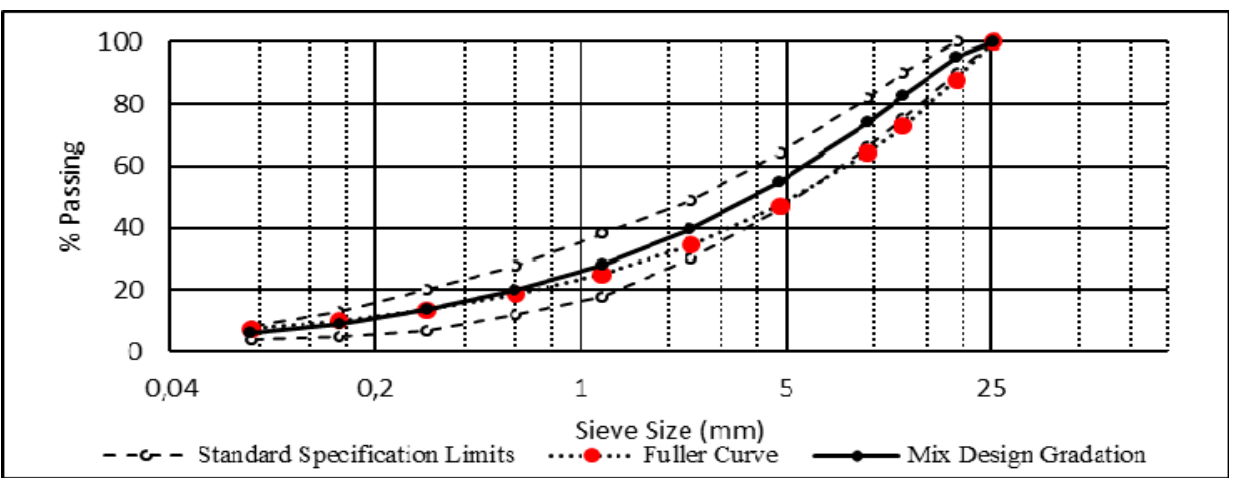

Fig. 1. The aggregate gradation of AC-BC asphalt mixed refers to the Bina Marga $20103^{\text {rd }}$ Revision Specification.

The graded aggregate of asphalt mixture used is for concrete binder course (AC-BC) asphalt mixture according to Bina Marga 2010 revision three specifications by taking the mean value of the existing gradation boundary in the specification (see Fig.1). The reference specifications are also used to determine the limits of aggregate properties, 
asphalt properties, and asphalt mixtures. Asbuton briquettes are solved and then mixed into the asphalt pen $60 / 70$ with a certain percentage and stirred there temperature $+150^{\circ} \mathrm{C}$ for 30 minutes. In this study, the percentage of Asbuton semi-extraction usage is $15 \%, 20 \%$ and $25 \%$ of the total asphalt weight.

From the results of extraction testing on Asbuton briquettes with a Soxhlet, it is known that the mineral content of Asbuton is $60.05 \%$ and Bitumen is $39.95 \%$. The sieve analysis was analyzed on Asbuton mineral extracted and obtained a finer particle content of 150 microns of $92.97 \%$, (see Table 1). In this study, Asbuton mineral is calculated as part of the aggregate-asphalt mixture. The result of the Asbuton mineral filter as the correction of the aggregate gradation used following the Asbuton content used.

Table1. Gradation of extracted mineral Asbuton.

\begin{tabular}{|c|c|c|}
\hline \multicolumn{2}{|c|}{ Sieve Size } & \multirow{2}{*}{ \% Passing } \\
\hline Inch & mm & 100.00 \\
\hline No. 16 & 1.18 & 99.29 \\
\hline No. 30 & 0.60 & 97.37 \\
\hline No. 50 & 0.30 & 92.97 \\
\hline No. 100 & 0.15 & 82.10 \\
\hline No. 200 & 0.074 & \\
\hline
\end{tabular}

Rheological characteristics of the binder, i.e., complex modulus $\left(\mathrm{G}^{*}\right)$ and phase angle $(\delta)$ were determined by using Dynamic Shear Rheometer (DSR). Four groups of the bituminous mixture with different binder composition were prepared. The binder of each group was: (i) all petroleum bitumen, (ii) blend of pen grade bitumen with $15 \%$ Asbuton semi extraction, (iii) blend of pen grade bitumen with $20 \%$ Asbuton semi extraction, and (iv) blend of pen grade bitumen with $25 \%$ Asbuton semi extraction. Variations in use of synthetic zeolite Aspha-min ${ }^{\circledR}$ were $0.3 \%, 0.6 \%$, and $1.0 \%$ of the total weight of the asphalt mixture. WMA manufacturing temperature was $30^{\circ} \mathrm{C}, 20^{\circ} \mathrm{C}$, and $10^{\circ} \mathrm{C}$ lower than Hot Mix Asphalt (HMA). HMA-making temperature is determined by values from the viscosity test.

\section{Results and discussion}

\subsection{Properties asphalt modified asbuton semi extraction}

The addition of semi-extraction Asbuton as bitumen modified material affects the bitumen properties. Test results of Asphalt pen grade as in Table 2 and modified asphalt properties with semi-extraction Asbuton as in Table 3. From the test results of asphalt properties, it is seen that the addition of Asbuton semi extraction decreases penetration value and increases the value of softening point. This indicates that the addition of semi-extraction Asbuton makes the modified asphalt harder than the 60/70 asphalt pen. The result of asphalt viscosity test also showed that the addition of semi extraction Asbuton increased the viscosity value of asphalt. The increase of viscosity value resulted in mixing, and compaction temperature also rose. The mixing and compaction temperatures of each type of asphalt are shown in Table 4. 
Table 2. Characteristics of the petroleum asphalt pertamina 60/70 penetration grade.

\begin{tabular}{|c|c|c|c|}
\hline Characteristics & $\begin{array}{c}\text { Standard test } \\
\text { procedure }\end{array}$ & $\begin{array}{c}\text { Test } \\
\text { result }\end{array}$ & Spec. limit \\
\hline Penetration $\left(25^{\circ} \mathrm{C}, 0.1 \mathrm{~mm}\right)$ & ASTM D 5 & 66.7 & $60-70$ \\
\hline Softening point $(\mathrm{C})$ & ASTM D 36 & 49.5 & Min. 48 \\
\hline Viscosity at $65^{\circ} \mathrm{C}(\mathrm{Pa} \mathrm{s})$ & ASTM D 4402 & 245.1 & $160-240$ \\
\hline Viscosity at $135^{\circ} \mathrm{C}(\mathrm{cSt})$ & AASHTO T 72-90 & 529.7 & Min. 300 \\
\hline Ductility at $25^{\circ} \mathrm{C}, 5 \mathrm{~cm} / \mathrm{minute}(\mathrm{cm})$ & ASTM D 113 & $>100$ & Min. 100 \\
\hline Flash point $\left(\mathrm{Cleveland} \mathrm{Open} \mathrm{Cup)}\left({ }^{\circ} \mathrm{C}\right)\right.$ & ASTM D 92-02B & 349 & Min. 232 \\
\hline Solubility in Trichloroethylene $(\%)$ & AASHTO T 44-03 & 99.87 & Min. 99 \\
\hline Specific gravity & ASTM D 92 & 1.037 & Min. 1 \\
\hline Loss on heating $(\mathrm{TFOT})\left(163^{\circ} \mathrm{C}, 5 \mathrm{~h}\right)(\%)$ & ASTM D 1754 & 0.417 & Max. 0.8 \\
\hline Retained penetration after TFOT $(\%)$ & ASTM D 5 & 66.72 & Min. 54 \\
\hline Viscosity at $65^{\circ} \mathrm{C}$ after TFOT (Pa s) & ASTM D 4402 & 544 & Max. 800 \\
\hline Ductility at $25^{\circ} \mathrm{C}, 5 \mathrm{~cm} /$ min after TFOT (cm) & ASTM D 113 & $>100$ & Min 100 \\
\hline
\end{tabular}

Table 3. Properties of modified asphalt properties with semi-extraction asbuton.

\begin{tabular}{|c|c|c|c|c|}
\hline \multirow{2}{*}{ Properties } & \multicolumn{3}{|c|}{ Test Result } & \multirow{2}{*}{$\begin{array}{l}\text { Spec. } \\
\text { limit }\end{array}$} \\
\hline & $\begin{array}{c}15 \% \\
\text { Asbuton }\end{array}$ & $\begin{array}{c}20 \% \\
\text { Asbuton }\end{array}$ & $\begin{array}{c}25 \% \\
\text { Asbuton }\end{array}$ & \\
\hline Penetration $\left(25^{\circ} \mathrm{C} ; 0.1 \mathrm{~mm}\right)$ & 57.10 & 54.00 & 50.60 & Min. 50 \\
\hline Softening point $(\mathrm{C})$ & 54.25 & 55.00 & 56.75 & Min. 53 \\
\hline Viscosity at $65^{\circ} \mathrm{C}$ (Pa s) & 283.90 & 437.00 & 480.00 & $240-360$ \\
\hline Viscosity at $135^{\circ} \mathrm{C}(\mathrm{cSt})$ & 614.76 & 636.56 & 776.08 & $385-2000$ \\
\hline Ductility at $25^{\circ} \mathrm{C}, 5 \mathrm{~cm} /$ minute $(\mathrm{cm})$ & $>100$ & $>100$ & $>100$ & Min. 100 \\
\hline Flash point (Cleveland Open Cup) $\left({ }^{\circ} \mathrm{C}\right)$ & 336.00 & 330.00 & 328.00 & Min. 232 \\
\hline Specific gravity & 1.091 & 1.123 & 1.163 & Min. 1 \\
\hline Loss on heating (TFOT) $\left(163^{\circ} \mathrm{C} ; 5 \mathrm{~h}\right)(\%)$ & 0.044 & 0.073 & 0.066 & Max. 0.8 \\
\hline Retained penetration after TFOT (\%) & 84.76 & 87.04 & 85.57 & Min. 54 \\
\hline Viscosity at $65^{\circ} \mathrm{C}$ after TFOT (Pa s) & 718 & 948 & 1070 & $\begin{array}{l}\text { Max. } \\
1200\end{array}$ \\
\hline Ductility at $25^{\circ} \mathrm{C}, 5 \mathrm{~cm} / \mathrm{min}$ after TFOT $(\mathrm{cm})$ & $>100$ & $>100$ & $>100$ & Min 50 \\
\hline
\end{tabular}


Table 4. Temperature mixing and compaction for HMA of each type of asphalt.

\begin{tabular}{|c|c|c|}
\hline Asphalt Type & $\begin{array}{c}\text { Mixing } \\
\text { Temperature }\left({ }^{\circ} \mathbf{C}\right)\end{array}$ & $\begin{array}{c}\text { Compacting } \\
\text { Temperature } \\
\left({ }^{\circ} \mathbf{C}\right)\end{array}$ \\
\hline Pen Grade Bitumen 60/70 (0\% Asbuton) & 157 & 147 \\
\hline Pen Grade Bitumen + 15\% Asbuton & 163 & 153 \\
\hline Pen Grade Bitumen + 20\% Asbuton & 167 & 157 \\
\hline Pen Grade Bitumen $+25 \%$ Asbuton & 170 & 159 \\
\hline
\end{tabular}

\subsection{The mechanistic properties of modified asphalt extraction semi asbuton}

Temperature changes will affect the value of Slide Modulus of asphalt Complex. Viscoelastic properties of asphalt increased temperature will decrease the modulus of the asphalt complex as shown in Fig. 2.

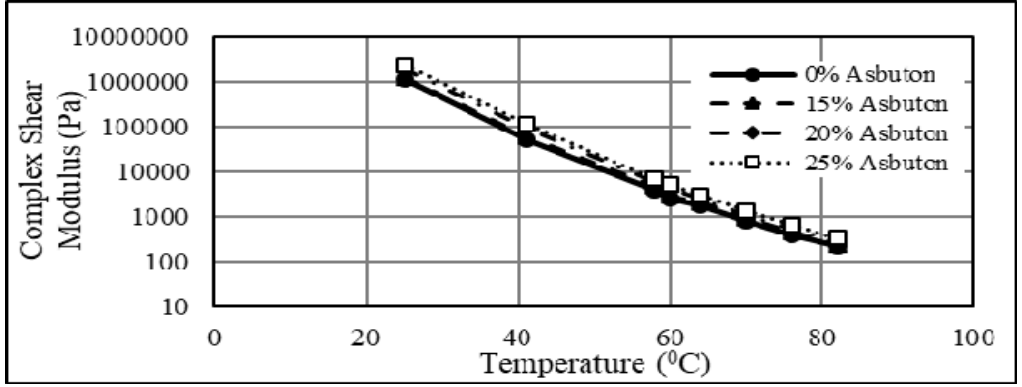

Fig. 2. Temperatures relationship with Complex Shear Modulus $\left(G^{*}\right)$ at variations additions asbuton semi extraction.

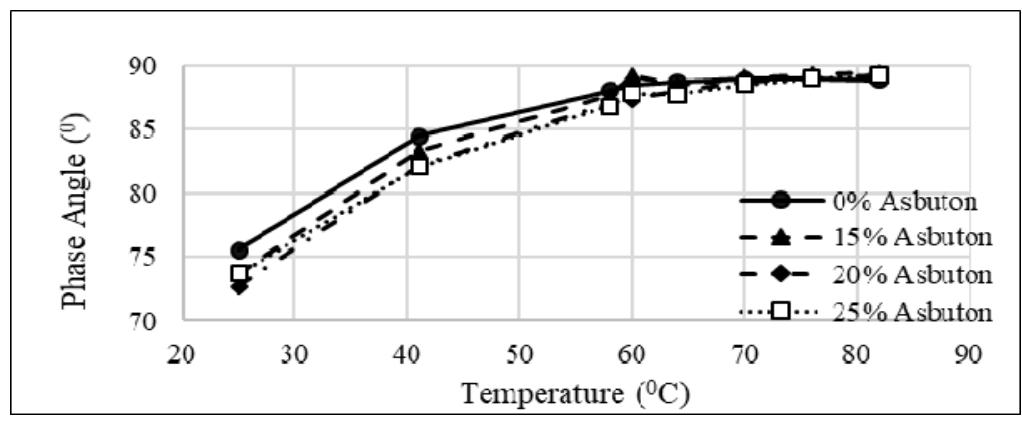

Fig. 3. Temperatures relationship with Phase Angle at variations additions asbuton semi extraction.

To find out the proportion of elastic properties $\left(G^{\prime}\right)$ with viscous $\left(G^{\prime \prime}\right)$ properties of asphalt to temperature can be observed from the Phase Angle relationship to temperature as in Fig. 3. From these relationships, it can be seen that the value of Phase Angle which is an indication of the proportion of the value of Loss Modulus or the viscous nature of the asphalt will increase with the addition of temperature since the temperature increase will decrease the asphalt elastic part. The addition of semi-extraction Asbuton decrease the Angle Phase value, since the addition of semi-extraction Asbuton may increase the elastic part of the asphalt. Semi-extraction Asbuton addition increases the PG of asphalt, from PG 
67.5 on the asphalt pen $60 / 70$, to PG 68.2 with $15 \%$ Asbuton, and to PG 71 with $20 \%$ Semiextraction Asbuton, and to PG 72 with 25\% Extraction Asbuton.

\subsection{Marshall properties hot mix asphalt modified asbuton semi extraction}

Based on the weight of asphalt used, semi-extraction Asbuton addition level increases the optimum asphalt content (Table 6). However, concerning asphalt content in the mixture, the addition of Asbuton semi extraction decreases the optimum asphalt content. This occurs because Asbuton semi extraction mix contains Asbuton mineral which is considered as part of aggregate. At the optimum asphalt rate, the addition of semi extraction Asbuton decreases the void in the mixture (VIM) and the filled voids with bitumen (VFB).

Table 6. Marshall test results on optimum asphalt content conditions.

\begin{tabular}{|c|c|c|c|c|c|c|}
\hline \multirow[b]{2}{*}{ Marshall properties } & \multicolumn{2}{|c|}{$\begin{array}{c}\text { Pen grade } \\
\text { asphalt }\end{array}$} & \multicolumn{4}{|c|}{ Asphalt modification with asbuton } \\
\hline & $\begin{array}{l}\text { Test } \\
\text { result }\end{array}$ & $\begin{array}{c}\text { Spec } \\
\dot{ } \\
\text { limit }\end{array}$ & $\begin{array}{c}15 \% \\
\text { asbuton }\end{array}$ & $\begin{array}{c}20 \% \\
\text { asbuton }\end{array}$ & $\begin{array}{c}25 \% \\
\text { asbuton }\end{array}$ & $\begin{array}{l}\text { Spec. } \\
\text { limit }\end{array}$ \\
\hline Asphalt mod. optimum cont. (\%) & & & 5.65 & 5.69 & 5.84 & \\
\hline Pure asphalt optimum cont. (\%) & 5.29 & & 5.14 & 5.50 & 4.96 & \\
\hline Air Void in Mix (VIM) (\%) & 3.963 & $3-5$ & 4.748 & 4.813 & 4.949 & $3-5$ \\
\hline Air Void in Aggregate (VMA) (\%) & $\begin{array}{c}14.88 \\
5\end{array}$ & $\begin{array}{c}\text { Min. } \\
14\end{array}$ & 15.655 & 15.198 & 14.377 & Min. \\
\hline Void Filled Bitumen (VFB) (\%) & $\begin{array}{c}73.38 \\
9\end{array}$ & Min. & 69.677 & 68.357 & 65.578 & $\underset{65}{\operatorname{Min} .}$ \\
\hline Marshall stability (Kg) & $\begin{array}{c}1331 . \\
3\end{array}$ & $\begin{array}{l}\text { Min. } \\
800\end{array}$ & 1884.3 & 2077.3 & 2332.8 & $\begin{array}{l}\text { Min. } \\
1000\end{array}$ \\
\hline Flow (mm) & 3.830 & $2-4$ & 3.493 & 3.350 & 3.333 & $2-4$ \\
\hline Marshall Quotient (Kg/mm) & 347.8 & & 543.7 & 621.1 & 707.3 & \\
\hline Index Retained Strength (IRS) (\%) & $\begin{array}{c}96.60 \\
8\end{array}$ & $\begin{array}{l}\text { Min. } \\
90\end{array}$ & 92.081 & 91.143 & 84.205 & $\begin{array}{c}\text { Min. } \\
90\end{array}$ \\
\hline
\end{tabular}

Voids between aggregates (VMA) of mix with addition of $15 \%$ Asbuton extraction is higher than without addition of semi-extraction Asbuton. The value of VMA decreases with the increase of semi-extraction Asbuton. The addition of semi-extraction Asbuton increase stability and reduce the flow even though the flow rate decrease is not too significant. From the increase of stability and flow rate values, addition of semi-extraction Asbuton increases mix stiffness, which could be observed from the increase of Marshall quotient (MQ) value. To find out the magnitude of stiffness, it requires modulus testing. The results of residual stability tests after a 24 -hour immersion at $60^{\circ} \mathrm{C}$ showed that the addition of Asbuton semi extraction decreased the Index Retained Strength (IRS). Addition of semi-extraction Asbuton $25 \%$ produced the IRS value below the value required in the specification. From this result, the use of semi-extraction Asbuton as bitumen modification material is only effective up to $20 \%$. 


\subsection{Marshall properties warm mix asphalt with zeolite synthetic}

The addition of zeolite to the asphalt mixture increased optimum asphalt content (OAC).

The increase of optimum bitumen content along with the rise of zeolite addition. The lower

Table 7. The Marshall test result for asphalt mixture with the asphalt pen grade and Aspha-min ${ }^{\circledR}$ synthetic zeolite additive.

\begin{tabular}{|c|c|c|c|c|c|c|c|c|c|c|}
\hline $\begin{array}{c}\text { Mixing } \\
\text { temp } \\
\left({ }^{\circ} \mathrm{C}\right)\end{array}$ & $\begin{array}{c}\text { Zeolite } \\
\text { content } \\
(\%)\end{array}$ & $\begin{array}{c}\text { OAC } \\
(\%)\end{array}$ & $\begin{array}{l}\text { Density } \\
\left(\mathrm{gr} / \mathrm{cm}^{3}\right)\end{array}$ & $\begin{array}{l}\text { VIM } \\
(\%)\end{array}$ & $\begin{array}{c}\text { VMA } \\
\text { (\%) }\end{array}$ & $\begin{array}{l}\text { VFB } \\
(\%)\end{array}$ & $\begin{array}{c}\text { Stabil. } \\
(\mathbf{K g})\end{array}$ & $\begin{array}{l}\text { Flow } \\
(\mathbf{m m})\end{array}$ & $\begin{array}{l}\text { MQ } \\
(\mathbf{K g} / \\
\mathbf{m m})\end{array}$ & $\begin{array}{l}\text { IRS } \\
(\%)\end{array}$ \\
\hline 157 & 0 & 5.27 & 2.391 & 3.963 & 14.894 & 73.405 & 1327.9 & 3.830 & 346.9 & 96.62 \\
\hline \multirow{3}{*}{127} & 0.3 & 5.38 & 2.388 & 4.001 & 14.988 & 73.352 & 1315.2 & 3.300 & 400.7 & 91.22 \\
\hline & 0.6 & 5.40 & 2.389 & 3.952 & 14.882 & 73.472 & 1310.4 & 3.383 & 387.2 & 81.06 \\
\hline & 1 & 5.50 & 2.392 & 3.814 & 14.761 & 74.169 & 1180.3 & 3.480 & 348.8 & 46.36 \\
\hline \multirow{3}{*}{137} & 0.3 & 5.30 & 2.390 & 4.119 & 14.867 & 72.311 & 1530.2 & 3.467 & 446.7 & 94.88 \\
\hline & 0.6 & 5.39 & 2.390 & 4.018 & 14.835 & 73.006 & 1526.0 & 3.700 & 418.1 & 86.46 \\
\hline & 1 & 5.42 & 2.392 & 3.856 & 14.669 & 73.733 & 1521.8 & 3.750 & 411.4 & 76.73 \\
\hline \multirow{3}{*}{147} & 0.3 & 5.29 & 2.390 & 4.199 & 14.833 & 71.698 & 1774.7 & 3.750 & 471.2 & 95.72 \\
\hline & 0.6 & 5.33 & 2.391 & 4.070 & 14.743 & 72.393 & 1639.8 & 3.883 & 422.6 & 87.40 \\
\hline & 1 & 5.35 & 2.393 & 3.906 & 14.589 & 73.233 & 1574.1 & 3.900 & 404.8 & 83.56 \\
\hline \multicolumn{2}{|c|}{ Spec. Limit } & & & $3-5$ & $>14$ & $>65$ & $>800$ & $2-4$ & & $>90$ \\
\hline
\end{tabular}

Table 8. The Marshall test result for asphalt mixture with the asphalt modification asbuton $15 \%$ and Aspha-min ${ }^{\circledR}$ synthetic zeolite additive.

\begin{tabular}{|c|c|c|c|c|c|c|c|c|c|c|}
\hline $\begin{array}{c}\text { Mixing } \\
\text { temp. } \\
\left({ }^{0} \mathrm{C}\right)\end{array}$ & $\begin{array}{c}\text { Zeolite } \\
\text { content } \\
(\%)\end{array}$ & $\begin{array}{c}\text { OAC } \\
(\%)\end{array}$ & $\begin{array}{l}\text { Density } \\
\left(\mathrm{gr} / \mathrm{cm}^{3}\right)\end{array}$ & $\begin{array}{l}\text { VIM } \\
(\%)\end{array}$ & $\begin{array}{c}\text { VMA } \\
(\%)\end{array}$ & $\begin{array}{l}\text { VFB } \\
(\%)\end{array}$ & $\begin{array}{c}\text { Stabil. } \\
(\mathbf{K g})\end{array}$ & $\begin{array}{l}\text { Flow } \\
(\mathrm{mm})\end{array}$ & $\begin{array}{l}\text { MQ } \\
(\mathrm{Kg} / \\
\mathrm{mm})\end{array}$ & $\begin{array}{l}\text { IRS } \\
(\%)\end{array}$ \\
\hline 163 & 0 & 5.65 & 2.376 & 4.748 & 15.757 & 69.874 & 1795.79 & 3.493 & 517.02 & 92.07 \\
\hline \multirow{3}{*}{133} & 0.3 & 5.83 & 2.374 & 5.007 & 15.744 & 68.202 & 1677.76 & 3.900 & 430.49 & 92.80 \\
\hline & 0.6 & 5.90 & 2.378 & 4.942 & 15.651 & 68.460 & 1703.05 & 3.917 & 434.84 & 82.48 \\
\hline & 1 & 5.93 & 2.381 & 4.635 & 15.494 & 70.084 & 1724.86 & 3.957 & 436.06 & 50.74 \\
\hline \multirow{3}{*}{143} & 0.3 & 5.81 & 2.378 & 5.179 & 15.743 & 67.110 & 1683.19 & 3.733 & 451.62 & 95.54 \\
\hline & 0.6 & 5.88 & 2.380 & 5.021 & 15.642 & 67.904 & 1713.41 & 3.743 & 458.53 & 85.90 \\
\hline & 1 & 5.90 & 2.382 & 4.745 & 15.461 & 69.308 & 1746.82 & 3.817 & 457.78 & 69.93 \\
\hline \multirow{3}{*}{153} & 0.3 & 5.80 & 2.378 & 5.332 & 15.716 & 66.080 & 1691.07 & 3.660 & 464.29 & 96.27 \\
\hline & 0.6 & 5.85 & 2.381 & 5.182 & 15.582 & 66.756 & 1716.88 & 3.677 & 468.20 & 89.79 \\
\hline & 1 & 5.88 & 2.382 & 4.882 & 15.423 & 68.346 & 1776.39 & 3.777 & 470.95 & 87.44 \\
\hline \multicolumn{2}{|c|}{ Spec. Limit } & & & $3-5$ & $>14$ & $>65$ & $>1000$ & $2-4$ & & $>90$ \\
\hline
\end{tabular}


mixing temperature of the required optimum bitumen content is higher. The reduction of mixing temperature to $30^{\circ} \mathrm{C}$ under HMA by the addition of synthetic zeolite yields a value of an asphalt mixture Marshall property still within the range of values required in the specification used. The lower mixing temperature of the optimum bitumen necessary content is higher. Increased synthetic zeolite saturation results in the value of the asphaltpinned IRS were decreasing. With addition of $1.0 \%$ zeolite, the IRS value was below the required value. From the test results obtained that the addition of zeolite as much as $0.3 \%$ at temperature mixing $30^{\circ} \mathrm{C}$ under HMA still meet the requirements (Table 7-9).

Table 9. The Marshall test result for asphalt mixture with the asphalt modification asbuton $20 \%$ and Aspha-min ${ }^{\circledR}$ synthetic zeolite additive.

\begin{tabular}{|c|c|c|c|c|c|c|c|c|c|c|}
\hline $\begin{array}{l}\text { Mixing } \\
\text { temp. } \\
\left({ }^{\circ} \mathrm{C}\right)\end{array}$ & $\begin{array}{c}\text { Zeolite } \\
\text { content } \\
(\%)\end{array}$ & $\begin{array}{c}\text { OAC } \\
(\%)\end{array}$ & $\begin{array}{l}\text { Density } \\
\left(\mathrm{gr} / \mathrm{cm}^{3}\right)\end{array}$ & $\begin{array}{l}\text { VIM } \\
\text { (\%) }\end{array}$ & $\begin{array}{l}\text { VMA } \\
\text { (\%) }\end{array}$ & $\begin{array}{l}\text { VFB } \\
\text { (\%) }\end{array}$ & $\begin{array}{c}\text { Stabil. } \\
\text { (Kg) }\end{array}$ & $\begin{array}{l}\text { Flow } \\
(\mathbf{m m})\end{array}$ & $\begin{array}{l}\text { MQ } \\
\text { (Kg/ } \\
\text { mm) }\end{array}$ & $\begin{array}{l}\text { IRS } \\
(\%)\end{array}$ \\
\hline 167 & 0 & $5.69 \%$ & 2.390 & 4.813 & 15.286 & 68.538 & 1879.81 & 3.350 & 561.38 & 91.15 \\
\hline \multirow{3}{*}{137} & 0.3 & $5.93 \%$ & 2.359 & 4.712 & 16.501 & 71.475 & 1450.12 & 3.740 & 389.00 & 93.60 \\
\hline & 0.6 & $5.98 \%$ & 2.378 & 4.380 & 15.776 & 72.235 & 1532.01 & 3.790 & 404.86 & 85.97 \\
\hline & 1 & $6.03 \%$ & 2.382 & 3.967 & 15.555 & 74.497 & 1724.13 & 3.803 & 455.00 & 63.47 \\
\hline \multirow{3}{*}{147} & 0.3 & $5.91 \%$ & 2.376 & 5.006 & 15.906 & 68.535 & 1690.40 & 3.787 & 445.44 & 94.01 \\
\hline & 0.6 & $5.96 \%$ & 2.383 & 4.567 & 15.590 & 70.732 & 1724.13 & 3.873 & 445.36 & 91.44 \\
\hline & 1 & $6.00 \%$ & 2.386 & 4.145 & 15.411 & 73.107 & 1911.29 & 3.890 & 494.16 & 82.05 \\
\hline \multirow{3}{*}{157} & 0.3 & $5.90 \%$ & 2.386 & 5.182 & 15.536 & 66.659 & 1867.45 & 3.583 & 545.46 & 95.71 \\
\hline & 0.6 & $5.95 \%$ & 2.391 & 4.743 & 15.288 & 68.981 & 1766.28 & 3.880 & 455.30 & 95.08 \\
\hline & 1 & $5.98 \%$ & 2.396 & 4.258 & 15.023 & 71.704 & 1957.88 & 3.880 & 505.59 & 88.49 \\
\hline \multicolumn{2}{|c|}{ Spec. Limit } & & & $3-5$ & $>14$ & $>65$ & $>1000$ & $2-4$ & & $>90$ \\
\hline
\end{tabular}

\section{Conclusions}

Based on the results, the following conclusions can be drawn. The addition of semiextraction Asbuton may decrease the value of the optimum bitumen content in the mixture, although the optimum bitumen content of modified asphalt is increased. Use of semiextraction of briquette Asbuton for effective asphalt modification to $20 \%$ of total asphalt weight. The reduction of mixing temperature to $300 \mathrm{C}$ below HMA mixing temperature with zeolite addition level of $0.3 \%$ still meets the requirements according to the specification used, in other words, WMA can be made using asphalt semi-extraction asphalt modification with $0.3 \%$ synthetic zeolite addition.

This research was supported by DRPM Kementerian Ristekdikti and LPPM Universitas Riau, under "Hibah Disertasi Doktor" schemes for FY 2018 (Contract No.: 271/UN.19.5.1.3/PP/2018). Thanks to PT. Olah Bumi Mandiri, PT. KADI International, and MHI Naturstein \& Baustoffservice GmbH for providing the material for this research. 


\section{References}

1. Shell, The shell bitumen handbook (Shell Bitument Internasional, London, 2003)

2. P. Pramesti, A.A.A Molenaar, M. Poot, Proc. of the 15th AAPA International Flexible Pavements Conference (2013)

3. K.A. Zamhari, M. Hermadi, M.H. Ali, Int. J. of Pavement Res. and Tech. 7, 1 (2014)

4. B.S. Subagio, R.H. Karsaman, J. Adwang, I. Fahmi, J. of the Eastern Asia Soc. for Transport. Studies 6 ( 2005)

5. F. Affandi, Jurnal Jalan dan Jembatan 25, 2 (2008)

6. F. Affandi, Jurnal Jalan dan Jembatan 27, 2 (2010)

7. A. Yamin, W. Pravantio, H. Dewita, Jurnal Poli Rekayasa 10, 1 (2014)

8. B.S. Subagio, H. Rahman, S. Hendarto, F.J. Philips, Proc. of the Eastern Asia Soc. for Transportation Studies 7 (2009)

9. N. Ali, Int. J. of Eng. and Tech. 3, 5 (2013)

10. M. Karami, H. Nikraz, Proc. Eng. 125 (2015)

11. F. Affandi, Jurnal Jalan-Jembatan 28, 2 (2011)

12. L. Sentosa, Y. Alwinda, Elianora, J. Susilo, Proc. of the 16th FSTPT International Symposium (2013)

13. A. Alonso, E, Tejeda, F. Moreno, M.C. Rubio, E. Medel, J. Materiales de Contruction 63. (2013)

14. A. Topal, B. Sengoz, B.V. Kok, M. Yilmaz, P.A. Dokandari, J. Oner, D. Kaya, Con. Build. Mat. 57 (2014)

15. A. Woszuk, Kulkielka, J.W. Franus, Academic J. \& Conferences of Lviv Polytechnic National University 781, 221-229 (2014)

16. R. Vaiana, T. Iuele, V. Gallelli, Int. J. Pavement Res. Tech. 6, 5 (2013)

17. F. Affandi, H. Hadisi, Jurnal Jalan dan Jembatan 28, 1 (2011) 